\title{
Outbreaks of Ebola virus disease in Africa: the beginnings of a tragic saga
}

\author{
Jean-Philippe Chippaux ${ }^{1,2}$
}

\begin{abstract}
The tremendous outbreak of Ebola virus disease occurring in West Africa since the end of 2013 surprises by its remoteness from previous epidemics and dramatic extent. This review aims to describe the 27 manifestations of Ebola virus that arose after its discovery in 1976. It provides an update on research on the ecology of Ebola viruses, modes of contamination and human transmission of the disease that are mainly linked to close contact with an infected animal or a patient suffering from the disease. The recommendations to contain the epidemic and challenges to achieve it are reminded.
\end{abstract}

Keywords: Ebola, Outbreak, Virus, Hemorrhagic fever, Africa

\section{Introduction}

The outbreak of Ebola virus disease (EVD) occurring in West Africa since December 2013 will mark the history however brief - of the viruses. Occurring for the first time outside its original home - the Central African rainforest - this epidemic of EVD appears as the deadliest and longest of all those known so far. At this time (August 15th, 2014), more than 1,250 deaths have been reported, i.e. five times more than during the worst previous outbreak. In addition, its rapid propagation has led the World Health Organization (WHO) to declare on August 8th that EVD represent a "Public Health Emergency of International Concern" and urged the international community to take action to stop the spread. Finally, for the first time, in response to the severity of the situation, WHO agreed the use of experimental treatment against the EVD.

\section{Review}

Discovered in 1976 during two inaugural epidemics, both in Sudan and Democratic Republic of Congo (DRC), the Ebola viruses were responsible for 27 occurrences in Africa before the current outbreak of Guinea. This review aims to remind the characteristics of the different epidemics of EVD that were reported between 1976 and 2013.

Correspondence: jean-philippe.chippaux@ird.fr

'UMR 216, Mother and Child Facing Tropical Diseases, Institut de Recherche pour le Développement (IRD), Cotonou, Bénin

${ }^{2}$ Université Paris Descartes, Sorbonne Paris Cité, Faculté de Pharmacie, Paris, France

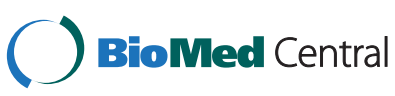

\section{Ebola viruses}

The Ebola virus is, together with Marburg marburgvirus, native to East Africa, and belongs to the Filoviridae family (Table 1), whose newest member is Lloviu cuevavirus, recently isolated in Spain from bats [1-3].

Ebola viruses are RNA viruses whose genome encodes seven proteins $[4,5]$. They are of filamentary form, sometimes branched, with a diameter of $80 \mathrm{~nm}$ and a length of up to $14,000 \mathrm{~nm}$ (Figure 1). The protein shell encloses the tubular helical nucleocapsid. Surface transmembrane glycoproteins of the virion provide the binding and fusion with the cell membrane, and penetration into the cell. Glycoproteins are responsible for almost all the virulence, even though it does not explain all the pathogenicity [6]. Monocytes, particularly macrophages, are the first cells infected, triggering apoptosis in lymphocytes [7]. Within three days, the virions invade the endothelial system $[4,5]$. The inhibition of the immune response, including reduced production of interferon, favors the rapid spread of the virus in the body $[8,9]$.

The genus Ebola comprises five species, including the four African species involved in human clinical cases $[3,10]$. Three of them were identified during Central African epidemics: first, Sudan ebolavirus and Zaire ebolavirus, both in 1976 respectively in Sudan and DRC, and more recently Bundibugyo ebolavirus, in 2007 in Uganda [11-14]. A fourth species, Taï Forest ebolavirus, was isolated from a primatologist who autopsied a chimpanzee in Côte d'Ivoire and survived the disease [15]. The last species, Reston ebolavirus, was isolated from monkeys native to Philippines 
Table 1 Filoviridae virus occurrences in the world

\begin{tabular}{|c|c|c|c|c|c|c|}
\hline Viral species & $\begin{array}{c}\text { Year of } \\
\text { discovery }\end{array}$ & $\begin{array}{l}\text { Geographic } \\
\text { origin }\end{array}$ & $\begin{array}{l}\text { Number of } \\
\text { outbreaks }\end{array}$ & $\begin{array}{c}\text { Number of } \\
\text { human cases }\end{array}$ & $\begin{array}{c}\text { Number of } \\
\text { deaths (CFR) }\end{array}$ & CFR (\%) \\
\hline Marburg marburgvirus & 1967 & Uganda & 4 & 465 & 145 & 31 \\
\hline Sudan ebolavirus & 1976 & Sudan & 6 & 792 & 426 & 54 \\
\hline Zaire ebolavirus & 1976 & DR Congo & 12 & $1,388^{*}$ & $1,100^{*}$ & 79 \\
\hline Reston ebolavirus & 1989 & Philippines & 0 & 0 & 0 & - \\
\hline Taï Forest ebolavirus & 1994 & Côte d'Ivoire & 0 & 1 & 0 & - \\
\hline Bundibugyo ebolavirus & 2007 & Uganda & 2 & 208 & 78 & 38 \\
\hline Lloviu cuevavirus & 2010 & Spain & 0 & 0 & 0 & - \\
\hline
\end{tabular}

CFR: case fatality rate. *Excluding the current West African outbreak.

farms [16]. The disease is deadly to monkeys. However, no human cases have been reported to date despite the presence of antibodies proving the infection in pigs (also without clinical illness) and humans [17].

According to Carroll et al. [10], the nearest common ancestor of Marburg and Ebola viruses dates back to 1,300 years. The separation of Sudan ebolavirus and other species of Ebola would have occurred soon after (about 1,200 years). The other species would have been separated much later, probably in the last hundred years or less (Figure 2).

\section{Clinical presentation}

Incubation ranges from 3 to 21 days [21]. Eichner et al. [22] determined that the incubation period was $12.7 \pm 4.3$ days, which fixes the average time between two generations of patients. The epidemic is considered complete after an interval of at least twice the maximum incubation period, i.e. 42 days after the death or recovery of the last confirmed case [23].

The disease lasts 5 to 15 days [24]. It begins suddenly with fever, headache, abdominal pain, arthralgia and myalgia, therefore the general picture resembles a flu syndrome [25-29]. About half of patients complain of cough and sore throat with dysphagia. Digestive disorders (diarrhea, nausea, vomiting) follow in a variable proportion of patients. Hemorrhages occur in $30-80 \%$ of patients, mostly

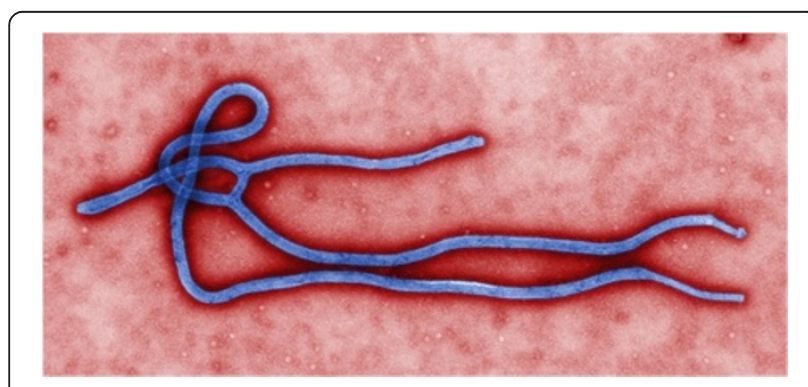

Figure 1 Ultrastructural morphology of Ebola virus virion (image by US Centers for Disease Control and Prevention and Cynthia Goldsmith). at the end of the illness, expressed by purpura, epistaxis, gingival bleeding, gastrointestinal bleeding or other, and appear to be associated with the severity of infection [24-30]. The variation in prevalence of symptoms, especially bleeding, is related to the viral species or clinical description that is based, according to the studies, on either suspected or confirmed cases.

Mortality is always high, although pathogenicity varies from one species to another (Table 1). In addition, some authors noted that mortality decreased during the epidemic. Several hypotheses have been advanced: loss of the virus virulence after successive generations, route of inoculation, viral load, improved management of cases and better enforcement of prophylaxis during the epidemic [24,26,30-33]. One cannot exclude that improving diagnosis in late epidemic reveals less severe cases.

\section{Diagnosis}

The clinical diagnosis is difficult at the beginning of the epidemics, because of the poor specificity of the symptoms $[24,27,29,30,33]$. When the virus responsible for the outbreak is identified, all suspected cases should be considered as high risk and meet the case definition and exposure risks (Tables 2 and 3) for better management of the epidemic. There is no carrier state.

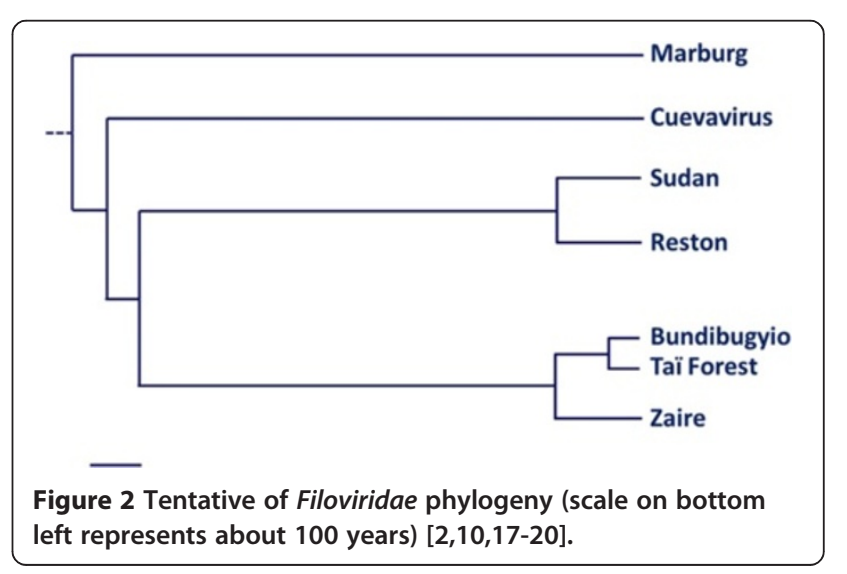


Table 2 Case definition of Ebola Virus Disease (EVD) [23,34]

\begin{tabular}{|c|c|}
\hline Name & Definition \\
\hline Index case & Very first case (probable or confirmed, see below) found to be the origin of the outbreak \\
\hline Alert case & $\begin{array}{l}\text { Any person with sudden onset of high fever or sudden death or bleeding or bloody diarrhea } \\
\text { or blood in urine }\end{array}$ \\
\hline \multirow[t]{2}{*}{ Suspect case (person under investigation) } & Any person, dead or alive, who present (or presented before the death): \\
\hline & $\begin{array}{l}\text { (i) fever ( }>38.5^{\circ} \mathrm{C} \text { or } 101.5^{\circ} \mathrm{F} \text { ) with additional symptoms (severe headache, muscle pain, vomiting, } \\
\text { diarrhea, abdominal pain, or unexplained hemorrhage) and (ii) epidemiologic risk factors within } \\
\text { the past } 21 \text { days before the onset of symptoms (close contact with body fluids of a suspect or } \\
\text { probable case of EVD, or direct handling of bush animals from disease-endemic areas) }\end{array}$ \\
\hline Probable case & $\begin{array}{l}\text { Person with symptoms compatible with EVD, as evaluated by a clinician, or a dead person with } \\
\text { an epidemiological link with a confirmed case }\end{array}$ \\
\hline \multirow[t]{2}{*}{ Contacts } & $\begin{array}{l}\text { Person without suggestive symptom of the disease, but who has been in contact with a suspect } \\
\text { or probable case of EVD (living in the same house, provided care during the illness, participated } \\
\text { in the burial rites etc.). It should be important to assess the risk level (see Table 3). }\end{array}$ \\
\hline & $\begin{array}{l}\text { If laboratory samples are obtained at an appropriate time during the illness, the previous notification } \\
\text { categories should be reclassified as "laboratory-confirmed" cases and "not a case" }\end{array}$ \\
\hline Confirmed case & Case with positive laboratory response for either Ebola virus antigen or Ebola IgG antibody \\
\hline "Not a case" & Person with no Ebola-specific detectable antibody or antigen \\
\hline
\end{tabular}

Laboratory diagnosis can only be performed in a specialized laboratory. First, there is no commercial reagent and, secondly, the samples represent an extreme biohazard that must be handled under containment conditions of the highest level (biosafety level $4-$ BSL-4; Figure 3).

In patients, the diagnosis is carried out by the detection of viral antigens through ELISA, identification of nucleic acid by PCR, specific antibody titer, or virus isolation. Specific IgM and IgG antibodies appear during the second week following the first clinical signs (about 15 to 20 days after the infection). IgM titers persist about two months whereas IgG titers remain several years after the end of the disease [37].

Virus isolation can be achieved by inoculation in mice, guinea pigs or non-human primates in whom the disease is very close to what is observed in humans. The virus grows on kidney cell lines from African green monkey Cercopithecus aethiops. The diagnosis is made by optical microscopy examination of cytopathic effects, visualization of the virions by electron microscopy, identification of specific proteins by ELISA, or RNA detection by PCR.

IgG titration allows retrospective diagnosis in convalescents or exposed persons, or epidemiological investigations even years after the epidemic.

\section{Treatment}

Antibodies acquired during the disease persist in survivors for more than ten years after the recovery. There is still no evidence that primary infection is protective in

Table 3 Definition and assessment of risk exposure [23,34-36]

\begin{tabular}{|c|c|}
\hline Risk level & Definition \\
\hline \multirow[t]{4}{*}{ High-risk exposure } & - Percutaneous injury, e.g. needlestick, or mucous membrane exposure to body fluids of an EVD patient \\
\hline & $\begin{array}{l}\text { - Direct care or exposure to body fluids of an EVD patient without appropriate personal protective } \\
\text { equipment (PPE) }\end{array}$ \\
\hline & $\begin{array}{l}\text { - Laboratory worker processing body fluids of confirmed EVD patients without appropriate PPE or } \\
\text { standard biosafety precautions }\end{array}$ \\
\hline & $\begin{array}{l}\text { - Participation in funeral rites that include direct contact with human remains in the geographic area } \\
\text { where an outbreak is occurring without appropriate PPE }\end{array}$ \\
\hline \multirow[t]{2}{*}{ Low-risk exposure } & - Household member or other casual contact ${ }^{1}$ with an EVD patient \\
\hline & $\begin{array}{l}\text { - Providing patient care or casual contact }{ }^{1} \text { without high-risk exposure with EVD patients in health care } \\
\text { facilities in EVD outbreak affected countries }\end{array}$ \\
\hline \multirow[t]{2}{*}{ No known exposure } & $\begin{array}{l}\text { Persons with no known exposure were present in an EVD outbreak affected country in the past } 21 \text { days } \\
\text { with no low-risk or high-risk exposures }\end{array}$ \\
\hline & $\begin{array}{l}{ }^{1} \text { Casual contact is defined as (i) being within approximately } 3 \text { feet ( } 1 \text { meter) or within the room or care } \\
\text { area for a prolonged period of time (e.g. healthcare personnel, household members) while not wearing } \\
\text { recommended personal protective equipment; or (ii) having direct brief contact (e.g., shaking hands) with } \\
\text { an EVD case while not wearing recommended personal protective equipment }\end{array}$ \\
\hline
\end{tabular}




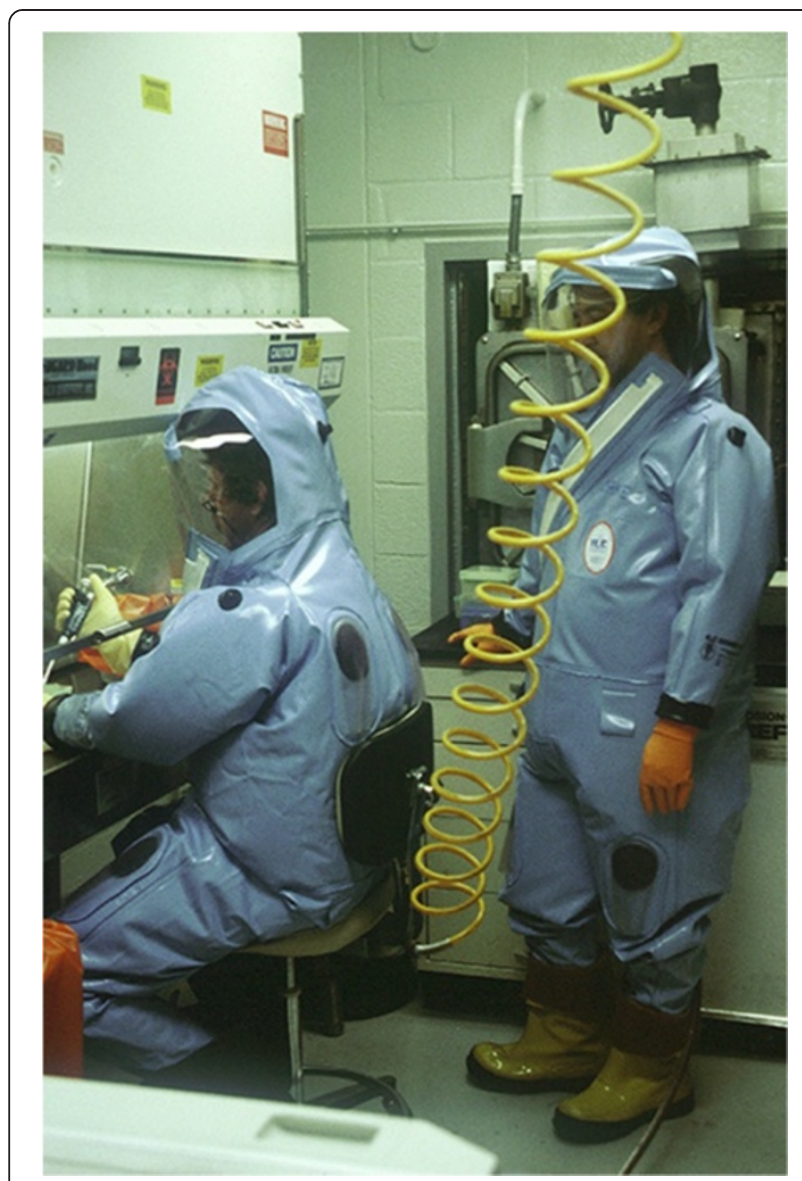

Figure 3 Study of Ebola virus in a high-security laboratory BSL-4 (photo by IRD, OIRD).

humans, apart from neutralization tests in vitro [38]. Moreover, up to this moment, there is no vaccine or effective treatment.

Studies on preventive vaccines are in progress $[39,40]$. Some of them showed very good efficacy and are produced under good manufacturing practices conditions. Phase I trials demonstrated that the drug is safe for humans [40]. However, vaccine development is hampered by limited commercial interests, even taking into account the risks of bioterrorism-related dispersion of such virus. The limited number of cases, despite the high mortality, adds to the complexity - and cost - of large-scale immunization of a scattered and often inaccessible population [41].

Post-exposure management should consider either passive immunotherapy, or administering drugs that block the action of the virus or its replication. Convalescent sera, thought to contain natural specific protective antibodies developed during the disease, have been used exceptionally, with some success $[42,43]$. It is noteworthy that these patients had also received better symptomatic treatments than regular patients, and were not representative.
However, despite this indisputable bias, several experimental studies have confirmed, particularly in nonhuman primates, the effectiveness of such approach [44]. The development of specific drugs is underway with some promising molecules, including monoclonal antibodies, which use is related to passive immunotherapy [45]. Recently, Warren et al. [46] showed that a new nucleoside analogue protects against infection with Filoviridae by inhibiting the viral polymerase in the Macacus cynomolgus model that, moreover, seems to tolerate well the treatment.

Symptomatic treatments are poorly documented because of the rarity of the disease (less than 2,500 known cases worldwide between 1976 and 2013) and the paucity of resources in endemic countries, which limits the choice of drugs [47]. Administration of antihemorrhagic drugs, substitution treatments, including transfusions, plasmapheresis or dialysis, and resuscitation are anecdotal and concern very few patients [47]. Although one of the main virus targets, interferon has not been an effective treatment, which confirms that the impairment of the immune system is deep $[4,5,47,48]$. Most often, palliative treatments are limited to rehydration with sugar solutions, preferably orally to avoid injections, analgesic, antipyretic, antiemetic, anti-diarrheal and sedatives or antipsychotic drugs to ease agitated and anxious patients.

\section{Natural history of ebola viruses}

The emergence, less than 50 years ago, of Ebola virus remains an enigma. It is possible that sporadic cases or limited outbreaks occurred in the past and were unreported due to lack of epidemiological surveillance or appropriate diagnosis. Scattered and minor manifestations of EVD suggest that Ebola viruses circulate in a pathogen complex showing no (or few) contacts with human populations. Destruction of forests and human impact on broader areas could explain the increased frequency and severity of outbreaks [49]. However, we cannot exclude a recent emergence of the virus that would spread rapidly in a susceptible population [50]. According to Polonsky et al. [51], increasing frequency of epidemics may result from the combination of: improvement of monitoring and diagnostic capacities, increase of contact among humans and the natural reservoirs of the virus, and growth of the viral load and prevalence of the virus in reservoirs.

Several epidemiological investigations in Central and East Africa have shown circulation of Ebola virus in the human population at a significant rate, but that does not always entail the emergence of an epidemic [24,52,53].

The natural reservoir of the virus is not known with certainty. Extensive investigations made in small mammals, even sensitive to the Ebola viruses, were negative during the various epidemics in Central Africa [26,54-56]. 
Subsequent investigations continued outside epidemics. Although viral RNA and specific antibodies have been identified in small mammals, no potential natural host has been acknowledged until 2005 [57]. However, initially dismissed due to many negative samples, fruit bats (Figure 4) were found with specific viral DNA and antibodies. These animals seem resistant to Filoviridae pathogenicity [18,58-63].

The search for potential vectors, especially among arthropods, has always proved negative, including bedbugs (Cimex hemipterus) captured in the beds of infected persons $[26,54,64,65]$.

Deadly outbreaks of Ebola virus have been observed in non-human primates with high mortality [66]. In addition to the contamination of the Swiss primatologist in Ivory Coast [15], the index case of several outbreaks have been more or less directly associated with hunting or consumption of bush meat, i.e. monkeys, antelopes, bats [26,58,65,67-71]. Natural infection of bats and sharing their narrow ecological niche with many species of nonhuman primates are strong arguments in favor of their role as a natural reservoir of the virus [58-61]. Some species, including Eidolon helvum, Hypsignathus monstrosus, Myonycteris torquata and Epomops franqueti, migrate long distances $(>2,500 \mathrm{~km})$, which could explain the multiple remote epidemic clusters $[58,72,73]$.

Seasonal variation in mortality in chimpanzees of the Tai forest, Ivory Coast, and prevalence of specific antibodies against Zaire ebolavirus virus in febrile patients from East Africa suggests an influence of the climate in the occurrences of Ebola epidemics [66,74]. Pinzon et al. [75] found a close relationship between the onset of epidemics and particularly dry conditions at the end of the rainy season, leading to a change in the behavior of fruit-eating mammals, particularly sensitive to weather changes, resulting in the increase of virus circulation or human contamination [76]. The seasons punctuate migration of bats, which could explain the emergence of epidemics $[58,62]$.

\section{Human transmission of Ebola viruses}

The contamination of index cases is probably due to contact with an infected animal. Human transmission happens only through close contact with an ill or convalescent person, although at this stage the risk of infection is very small. Studies conducted during the various epidemics have shown that less than one fifth of the people (see Tables 2 and 3) living with a confirmed or probable primary patient have developed the disease [24-26,35]. All secondary cases were recorded among people with close contact with the patient and exposed to infected biological fluids. Conversely, people who had no contact with the patient were not sick. Such close contact with the patient throughout care occur mainly during the illness or burial preparation, including washing the body and funeral ritual that can be long and intimate [25,26,77-79]. The risk greatly increases due to the delay in diagnosis and appropriate management $[24,27,29,30,33]$.

Ebola viruses have been detected in most patient secretions. They are present in the blood, saliva, feces, breast milk, tears and genital secretions. They have not been isolated from vomit, sputum, sweat or urine. However, the number of tested samples was low [80]. The virus persists in breast milk, genital secretions and glass during convalescence and up to 13 weeks after recovery $[27,80,81]$. Finally, the risk of transmission from fomites (towels, clothes and sheets from the patient), especially during convalescence, is low and basic protection measures are likely to be sufficient [80].

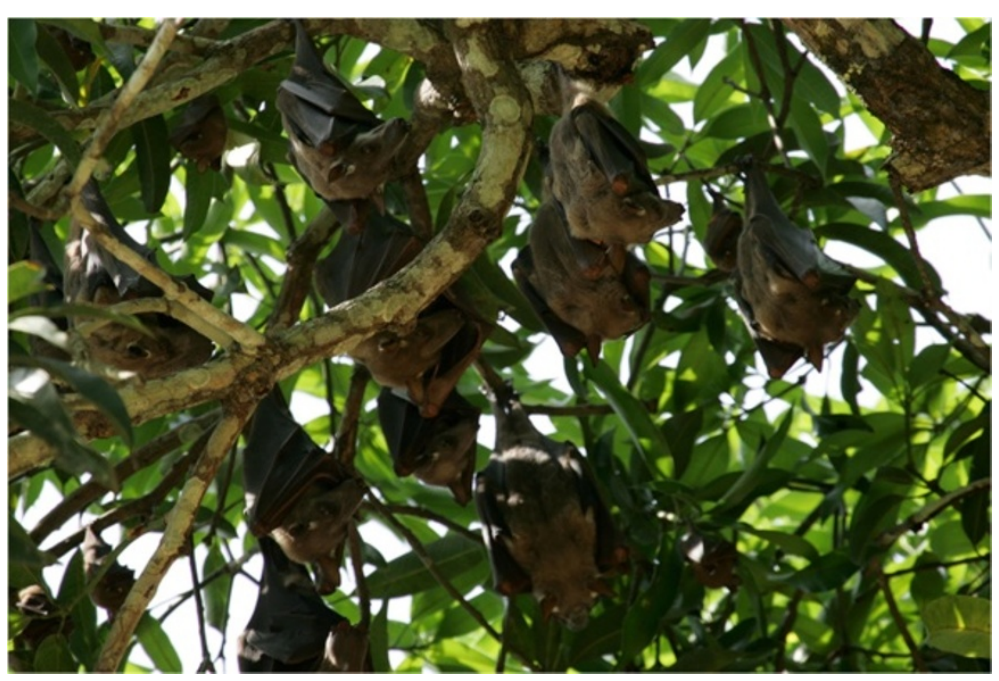

Figure 4 Group of bats Hypsignathus monstrosus in a mango tree in Lambaréné, Gabon (photo by Jean-Jacques Lemasson, OIRD). 
Nosocomial transmission is behind many hospital outbreaks $[21,24,28]$. Injection materials reused without precaution or inadequately sterilized have been repeatedly denounced and remain a major cause of epidemic spread. This also applies to traditional healers whose practices are often septic $[67,82]$.

Finally, all the studies performed during the outbreaks of EVD showed that contamination occurs due to close contact with the blood or secretions of an infected patient through three ways $[25,26,35,36]$ :

- Patient care - usually a family member takes care of the patient during the illness.

- Preparing the deceased for funeral before or during burial.

- Nosocomial transmission - reuse of medical equipment that has been previously used in a patient infected with Ebola virus.

There is no contamination by air or just handshake.

Manifestations of Ebola viruses in Africa (1976-2012)

Since their discovery in 1976, simultaneously in Sudan and DRC, and until 2012, i.e. the recent outbreaks observed in Uganda and again in the DRC, Ebola viruses were notified 27 times (Table 4, Figure 5), including in 22 epidemics. It is possible that sporadic cases or limited outbreaks have escaped any mention due to the remoteness and poverty of the concerned people.

Some individual infections, such as those observed in Tandala (DRC) in 1977, Taï (Côte d'Ivoire) in 1995, Luwero (Uganda) in 2011, indicate an occult but permanent circulation of Ebola viruses [15,83,95]. The confirmed case in Gozon (Côte d'Ivoire) in 1995, which may have come from Liberia, has not been completely documented and is not mentioned after the year 1999 [85,86]. The index case in Johannesburg in 1996 was a patient infected in Gabon, where he was staying during the Ebola outbreak in that country [82]. Finally, some epidemics may be the expression of successive waves of the same epidemic, as in Gabon in 1996, Gabon and Congo between 2000 and 2003, and Uganda in 2012, confirming the persistence of the Ebola virus.

Beyond the diversity of African outbreaks, particularly regarding the incidence and duration of the epidemics (Table 5), we can notice that most of them presented only one source of infection accounting for the spread of the virus. As a result, it can be assumed that either the opportunities for human contact with the virus are rare, or the risk of contamination is limited. The period between the index case and the alert averages about two months. In addition, an equivalent period occurs between the alert and the last confirmed case (Figure 6).
The origin of the disease and its management are not perceived the same way by different people $[77-79,82]$. At the beginning of epidemics, the disease is often confused with another endemic infection (such as malaria, dysentery, typhoid or yellow fever, influenza etc.), both by the general population and health personnel. When the incorrect causes are eliminated or diagnosis of EVD is confirmed, other explanations of cultural, religious, circumstantial or biomedical origins are proposed. It has been shown, in several epidemics, that affected people perceived the illness as divine punishment or evil spell, and even, sometimes, denied the disease itself [77-79]. Hesitations about diagnosis and the diversity of explanatory anthropological models result in the delay of the alert and difficulties in the implementation of measures against epidemics $[79,82,92]$.

Finally, health authorities, for economic and political reasons, take late measures that only aim at minimizing the stress provoked by epidemics and avoiding panic. This results in inadequate or contradictory information, which adds to the general stress. Moreover, some measures taken to demonstrate the determination of the authorities are useless and counterproductive. The ban of gatherings and travel, border closures, police cordons and other initiatives only reinforce distrust of people vis-à-vis the authorities and health personnel.

\section{Management of outbreaks}

The delay in clinical diagnosis and epidemic alert represent a major issue because it exacerbates the spread of the virus.

In the absence of any vaccine or post-exposure treatments, it is essential to break the chain of transmission by acting directly on the causes and circumstances of outbreaks. All the precautions should be taken for patient care, management of dead bodies, burial and surveillance of contacts [106]. The Centers for Disease Control and the World Health Organization provide a manual in English, French and Portuguese (http://www.cdc.gov/vhf/ abroad/vhf-manual.html) enabling health authorities to prepare for EVD outbreak management. After the description of the standard precautions regarding care of all patients to prevent infections (a brief summary of Good Medical Practice), the manual details the techniques used to control epidemics of EVD with many simple and practical hints:

- Clinical diagnosis of the disease.

- Isolation of the patient and planning the isolation area.

- Wearing appropriate clothing during treatment (Figure 7).

- Identification and monitoring of contacts. 
Table 4 Characteristics of the African manifestations of Ebola virus (bolded names indicate the place of first case occurrence)

\begin{tabular}{|c|c|c|c|c|c|c|c|c|c|c|}
\hline \multirow{2}{*}{ Year } & \multirow{2}{*}{ Country } & \multirow{2}{*}{ Districts } & \multirow{2}{*}{$\begin{array}{l}\text { Ebola } \\
\text { species }\end{array}$} & \multirow{2}{*}{$\begin{array}{l}\text { Length } \\
\text { (weeks) }\end{array}$} & \multicolumn{4}{|c|}{ Number of cases } & \multirow{2}{*}{$\begin{array}{l}\text { Ways of } \\
\text { transmission }\end{array}$} & \multirow{2}{*}{ References } \\
\hline & & & & & Presumed* & Confirmed & Deaths & Total & & \\
\hline \multirow[t]{2}{*}{1976} & Sudan & Nzara, Maridi, Tembura, Juba & Sudan & 22 & 227 & 57 & 151 & 284 & Nursing patient & {$[12,25]$} \\
\hline & & & & & & & & & Nosocomial** & \\
\hline \multirow[t]{2}{*}{1976} & DRC & Yambuku, Abumombazi, Kinshasa & Zaïre & 9 & 307 & 11 & 280 & 318 & Nursing patient & {$[11-13,26]$} \\
\hline & & & & & & & & & Funeral/burial ritual & \\
\hline 1977 & DRC & Tandala & Zaïre & - & & 1 & 1 & 1 & & [83] \\
\hline 1979 & Sudan & Nzara, Yambio & Sudan & 10 & 24 & 10 & 22 & 34 & Nursing patient & [24] \\
\hline 1994 & Gabon & Minkouka, Andock, Minkébé & Zaïre & 13 & 32 & 19 & 31 & 51 & Nursing patient & {$[67,82,84]$} \\
\hline 1994 & Côte d'Ivoire & Taї & Taï Forest & - & & 1 & 0 & 1 & & [15] \\
\hline \multirow[t]{2}{*}{1995} & Côte d'Ivoire /Liberia & Gozon & $?$ & & & 1 & 0 & 1 & & {$[85,86]$} \\
\hline & & & & & & & & & Nosocomial** & \\
\hline \multirow[t]{2}{*}{1995} & DRC & Kikwit, Mosango ( \pm 30 villages) & Zaïre & 27 & 233 & 82 & 255 & 315 & Nursing patient & {$[28,87]$} \\
\hline & & & & & & & & & Funeral/burial ritual & \\
\hline \multirow{2}{*}{1996} & & Mavihout & 7äro & 12 & 20 & 2 & 21 & 31 & Eating bush meat & 56707807 \\
\hline & Gabon & Mayıbout & Larre & 12 & 29 & 2 & 21 & 31 & Funeral/burial ritual & {$[0 /, 0<, 00]$} \\
\hline \multirow{2}{*}{1996} & Gabon & Booué, Balimba, Lastourville, Libreville & Zaïre & 27 & 56 & 4 & 45 & 60 & Eating bush meat & {$[67,82,89-91]$} \\
\hline & & & & & & & & & Nursing patient & \\
\hline 1996 & South Africa & Johannesburg & Zaïre & - & 0 & 2 & 2 & 2 & & [82] \\
\hline \multirow{3}{*}{2000} & Uaanda & Gulu Masindi Mbarara & Sudan & 20 & 230 & 195 & 224 & 425 & Nosocomial** & [21311] \\
\hline & & & & & & & & & Nursing patient & {$[21,31]$} \\
\hline & & & & & & & & & Nosocomial** & \\
\hline \multirow[t]{3}{*}{ 2001-2002 } & Gabon & Mékambo, Makokou, Franceville & Zaïre & 21 & 37 & 28 & 53 & 65 & Nursing patient & {$[69,82,34]$} \\
\hline & & & & & & & & & Funeral/burial ritual & \\
\hline & & & & & & & & & Nosocomial** & \\
\hline \multirow[t]{2}{*}{ 2001-2002 } & Congo & Mbomo, Kellé & Zaïre & $20 ?$ & 50 & 9 & 44 & 59 & Nursing patient & [34] \\
\hline & & & & & & & & & Funeral/burial ritual & \\
\hline 2002 & Congo & Mbomo & $?$ & 10 & 9 & & 8 & 9 & $?$ & [34] \\
\hline 2002 & Gabon & Ekata & $?$ & 10 & 2 & & 2 & 2 & $?$ & [34] \\
\hline 2002-2003 & Congo & Mbomo, Kellé & Zaïre & 17 & 130 & 13 & 128 & 143 & $\begin{array}{c}\text { Nursing patient } \\
\text { Funeral/burial ritual }\end{array}$ & [71] \\
\hline 2003 & Congo & Mbomo, Mbandza & Zaïre & 7 & 18 & 17 & 29 & 35 & Nursing patient & [92] \\
\hline & & & & & & & & נכ & Funeral/burial ritual & {$[92]$} \\
\hline 2004 & Sudan & Yambio & Sudan & 10 & 4 & 13 & 7 & 17 & Nursing patient & [93] \\
\hline
\end{tabular}


Table 4 Characteristics of the African manifestations of Ebola virus (bolded names indicate the place of first case occurrence) (Continued)

\begin{tabular}{|c|c|c|c|c|c|c|c|c|c|c|}
\hline 2005 & Congo & Etoumbi, Mbomo & Zaïre & 6 & 11 & 1 & 10 & 12 & $\begin{array}{l}\text { Funeral/burial ritual } \\
\text { Nursing patient } \\
\text { Funeral/burial ritual }\end{array}$ & [70] \\
\hline 2007 & DRC & Luebo & Zaïre & 17 & $\leq 170$ & $\geq 17$ & 186 & 264 & No data & {$[47,19]$} \\
\hline 2007 & Uganda & Bundibugy, Kikyo & Bundibugyo & 20 & 75 & 56 & 42 & 131 & $\begin{array}{c}\text { Nursing patient } \\
\text { Funeral/burial ritual }\end{array}$ & {$[29,30,33,94]$} \\
\hline 2008 & DRC & Luebo, Mweka & Zaïre & 5 & $\leq 29$ & $\geq 3$ & 15 & 32 & No data & [19] \\
\hline 2011 & Uganda & Luwero & Sudan & & & 1 & 1 & 1 & & [95] \\
\hline 2012 & Uganda & Kibale & Sudan & 11 & 13 & 11 & 17 & 24 & No data & {$[96,97]$} \\
\hline 2012 & Uganda & Luwero, Kampala & Sudan & 8 & 3 & 6 & 4 & 7 & $\begin{array}{c}\text { No data } \\
\text { Nosocomial** }\end{array}$ & [97-99] \\
\hline 2012 & DRC & Isiro, Pawa, Dungu & Bundibugyo & 29 & 41 & 36 & 36 & 77 & $\begin{array}{c}\text { Nursing patient } \\
\text { Funeral/burial ritual }\end{array}$ & {$[79,100]$} \\
\hline
\end{tabular}

*Alert, suspected or probable case, i.e. diagnosis based on clinical and/or epidemiological criteria but not biological evidence (see Table 3). In some outbreaks, case definition changed during the epidemics. **Hospital transmission due to needle and syringe contamination, contact with patient's blood, secretions or fomites. 


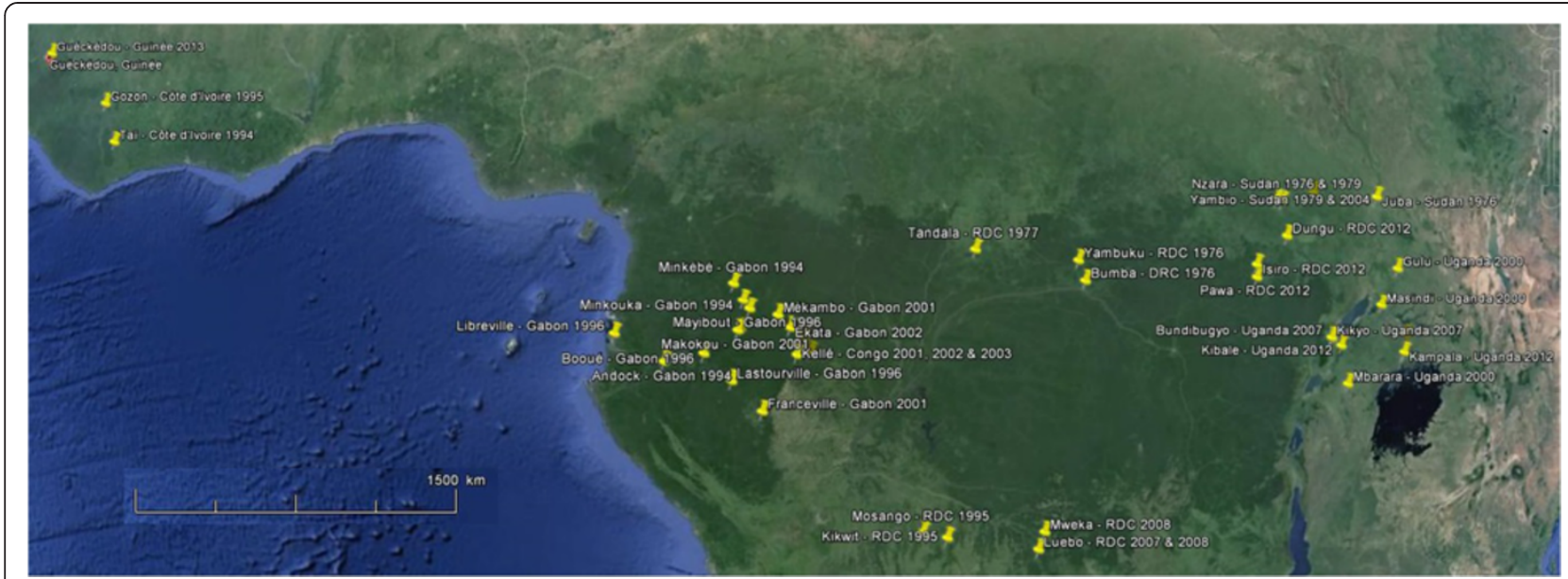

Figure 5 Geographical distribution of African manifestations of Ebola viruses (based on Google ${ }^{\mathrm{TM}}$ Earth map).

- Disinfection and sterilization of equipment and facilities.

- Waste disposal.

- Preparation of the body (Figure 8).

- Transportation to the place of burial (Figure 9).
However, the management of cases and now wellknown procedures face many difficulties that arise quickly in most outbreaks. In addition to the virulence of Ebola viruses and usual customs, it should be taken into account the changes in behavior induced

Table 5 Length of African Ebola outbreaks

\begin{tabular}{|c|c|c|c|c|c|c|}
\hline Outbreak & Index case & Alert & Last case & $\begin{array}{l}\text { Length of } \\
\text { outbreak* }^{*}\end{array}$ & $\begin{array}{l}\text { Number of } \\
\text { outbreak sources }\end{array}$ & References \\
\hline Sudan 1976 & Jun. 27, 1976 & Sep. 15, 1976 & Nov. 25, 1976 & 151 days & 1 & {$[25,101]$} \\
\hline DRC 1976 & Sep. 1, 1976 & Sep. 21, 1976 & Nov. 5, 1976 & 66 days & 1 & {$[26,102]$} \\
\hline Sudan 1979 & Jul. 31, 1979 & Sep. 12, 1979 & Oct. 6, 1979 & 67 days & 1 & {$[24,103]$} \\
\hline Gabon 1994-5 & Nov. 13, 1994 & Dec. $18,1994^{1}$ & Feb. 9, 1995 & 88 days & $?$ & {$[67,84,104]$} \\
\hline DRC 1995 & Jan. 6, 1995 & May 1, 1995 & Jul. 16, 1995 & 191 days & 1 & {$[28,87]$} \\
\hline Gabon 1996 & Jan. 31, 1996 & Feb. 13, 1996 & Mar. 12, 1996 & 83 days & 1 & {$[67,88,89]$} \\
\hline Gabon 1996-7 & Jul. 13, 1996 & Oct. 5, 1996 & Jan. 18, 1997 & 189 days & $?$ & {$[67,90,91]$} \\
\hline Uganda 2000-1 & Aug. 30, 2000 & Oct. 8, 2000 & Jan. 14, 2001 & 137 days & 1 & {$[21,105]$} \\
\hline Gabon 2001-2 & Oct. 25, 2001 & Nov. 17, 2001 & Mar. 22, 2002 & 148 days & 5 & {$[69,34]$} \\
\hline Congo 2001-2 & ND & ND & ND & ND & $?$ & [34] \\
\hline Congo 2002 & May 17, 2002 & June 6, 2002 & Jul. 25, 2002 & 69 days & 1 & [34] \\
\hline Gabon 2002 & May 17, 2002 & Jun. 21, 2002 & Jul. 25, 2002? & 69 days? & 1 & {$[34]$} \\
\hline Congo 2002-3 & Dec. 25, 2002 & Jan. 28, 2003 & Apr. 22, 2003 & 118 days & 3 & {$[71]$} \\
\hline Congo 2003 & Oct. 11, 2003 & Oct. 24, 2003 & Dec. 2, 2003 & 52 days & 1 & {$[92]$} \\
\hline Sudan 2004 & Apr. 15, 2004 & May 6, 2004 & June 26, 2004 & 72 days & 1 & {$[93]$} \\
\hline Congo 2005 & Apr. 18, 2005 & Apr. 26, 2005 & May 27, 2005 & 39 days & 1 & {$[70]$} \\
\hline DRC 2007 & Jun. 12, 2007 & Aug. 22, 2007 & Oct. 10, 2007 & 120 days & 1 & {$[58,19]$} \\
\hline Uganda 2007-8 & Aug. 20, 2007 & Sep. 15, 2007 & Jan. 8, 2008 & 141 days & 1 & {$[30,33,94]$} \\
\hline DRC 2008-9 & Nov. 27, 2008 & Dec. 25, 2008 & Jan. 1, 2009 & 34 days & 1 & [19] \\
\hline Uganda $2012^{2}$ & Jun. 11, 2012 & Jul. 24, 2012 & Aug. 24, 2012 & 74 days & 1 & {$[96,97]$} \\
\hline Uganda $2012^{2}$ & Oct. 13, 2012 & Nov. 14, 2012 & Dec. 5, 2012 & 53 days & 1 & [97-99] \\
\hline DRC $2012^{2}$ & Mar. 20, 2012 & Aug. 17, 2012 & Oct. 11, 2012 & 206 days & $?$ & {$[79,100]$} \\
\hline
\end{tabular}

*Between the index case and recovery or death of the last case. ${ }^{1}$ First reported as yellow fever [85]. ${ }^{2}$ Partial unconsolidated data. ND: not determined. 


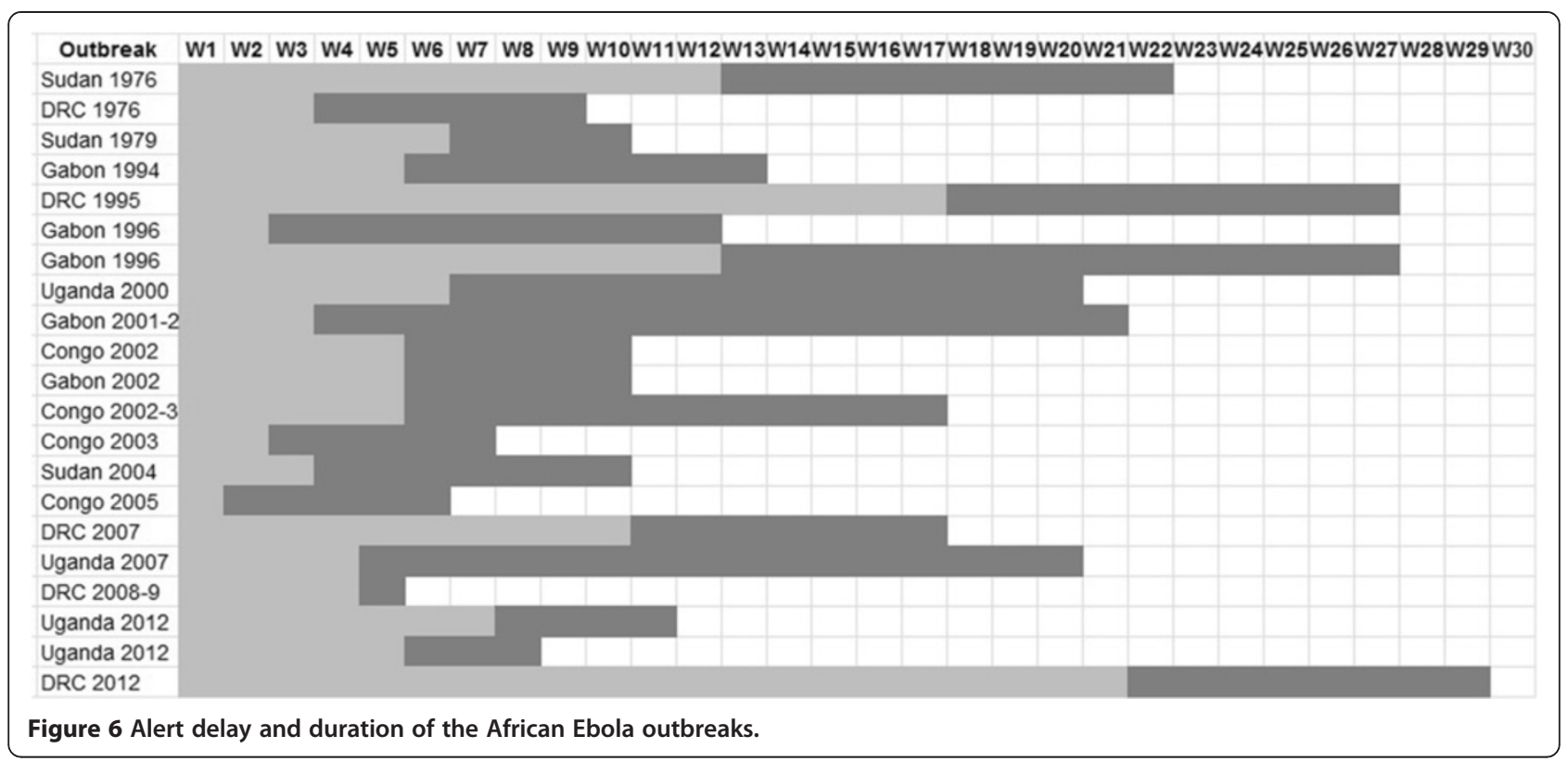

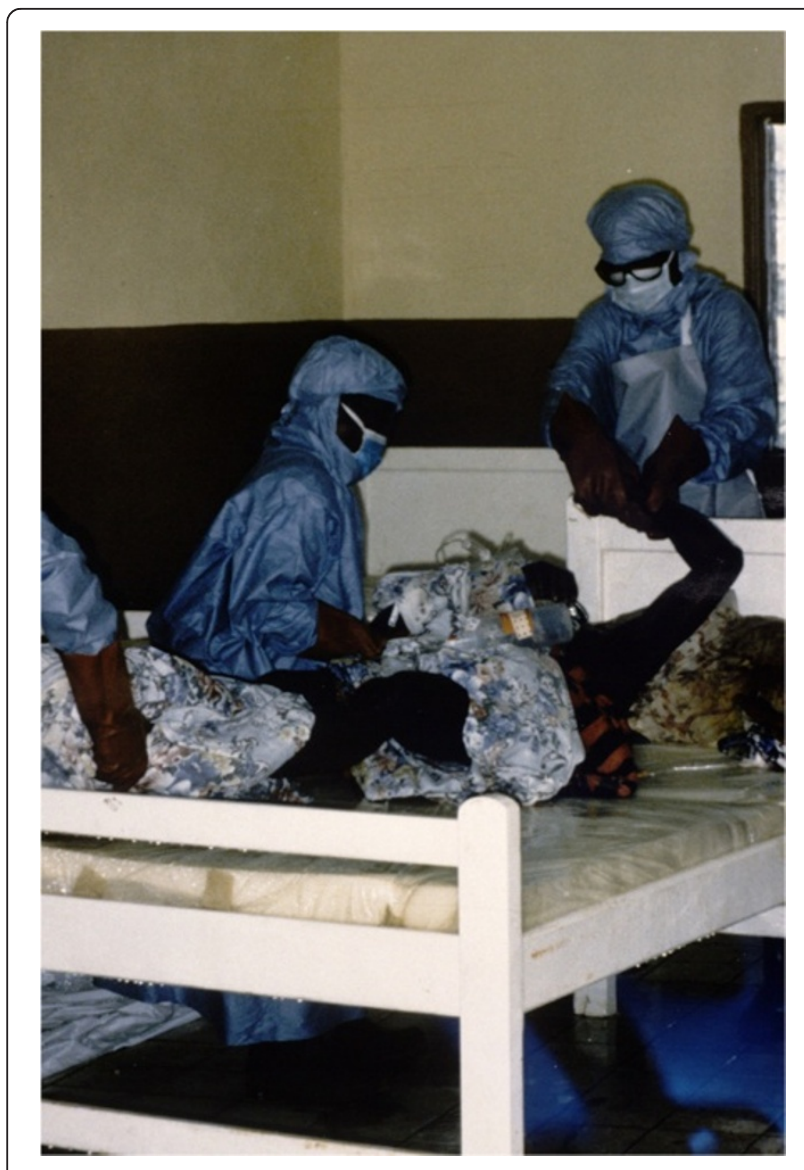

Figure 7 Protective clothing worn by healthcare personnel during the care and handling of a patient (photo by Jean-Paul Gonzalez, OIRD). by the fear generated by the epidemic and associated rumors.

Traditional practices regarding patient care and burial rituals often involve high risk conducts, such as washing and preparation of the body for exposure for several days, during which family and friends pay tribute by stroking or hugging the deceased [77-79,82,92]. Before appropriate measures are taken, which may take several weeks or months, the deceased persons are transported to their home community where people sometimes come from far away to attend the funeral and then go back home, which enables the spreading of the virus. The always frightening and often contradictory messages and rumors - prompt patients to avoid going to the hospital due to fear of isolation and because of the lack of effective treatments. It becomes impossible to identify the cases, confirm diagnosis, protect and monitor contacts. Violent protests - with loss of life, involving sometimes the medical staff - have been reported in some outbreaks $[71,82,92]$.

Other variables that hinder the adequate management of outbreaks include training of health workers who fail to immediately identify the disease, especially in areas where EVD has never been observed, either because of nonspecific clinical symptoms or lack of experience. Anyway, to date, there is no diagnostic test able to confirm an EVD suspicion. In addition, protective and disinfection equipment are usually absent and slow to become available in numerous health facilities [82]. Nosocomial transmission through contaminated and poorly (or not) sterilized medical instruments is a major multiplication factor in most outbreaks. Such picture is worsened by the fact that they hit in remote and poor regions. 


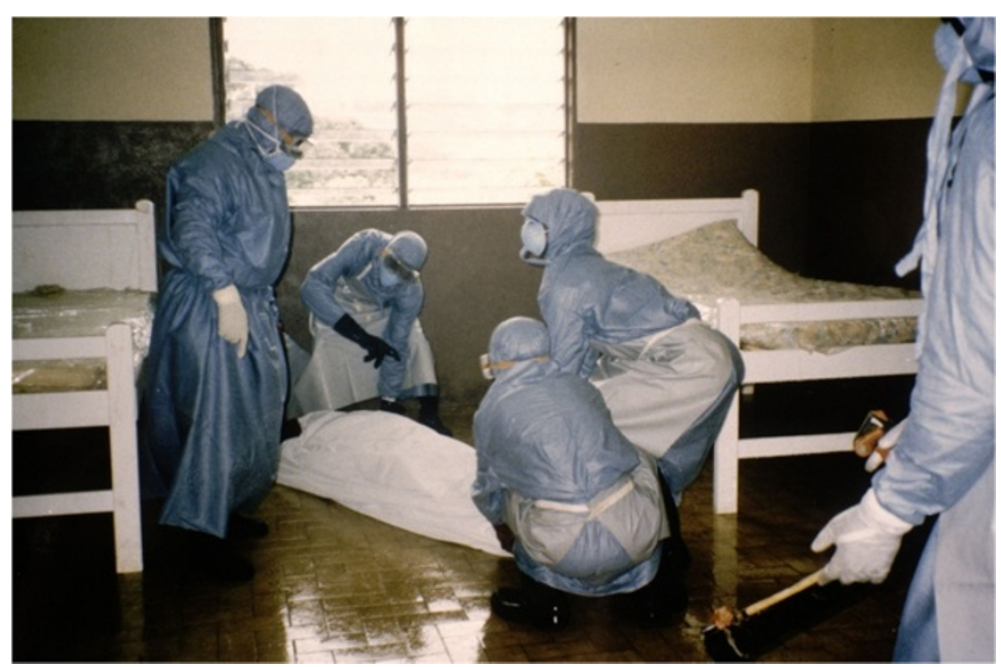

Figure 8 Wrapping of the body in a mortuary sac (photo by Jean-Paul Gonzalez, OIRD).

Social mobilization is a key component because all stakeholders should be involved to enable pooling resources and optimizing management of epidemics [71]. The ethical aspects should not be overlooked. Isolation of patients, required to avoid contamination, should not be seen as segregation. The family should be able to see and talk to patients, even if they are prevented from touching them. Authorities and medical staff should comply with, as far as possible, funeral rites by providing body bags and coffins for the families [92]. For instance, decontamination will be presented as ablutions that can be associated with the current ritual; deceased's clothes will be buried in the grave rather than burned to prevent stigmatization etc. [71,77-79].

After the epidemic, it is important to reseal the bonds of community through social, cultural and sporting activities.

\section{Conclusion}

Recently discovered in Central Africa, the Ebola viruses caused limited, but high-mortality epidemics. Fruit bats are probably the reservoir of the virus. The initial human infection results from contact with infected bush meat, and usually takes place in poor and inaccessible areas. Secondary transmission occurs during patient care at home, funeral rites or hospital dissemination due to the lack of preventive measures and because of inadequate training of health personnel with good medical practice.

The difficult diagnosis, the resistance of the population and the reluctance of authorities explain the slow and limited response to outbreaks, and the rapid spread of the epidemic that becomes hard to control.

In the absence of effective treatment, the discovery of an Ebola outbreak demands breaking the transmission

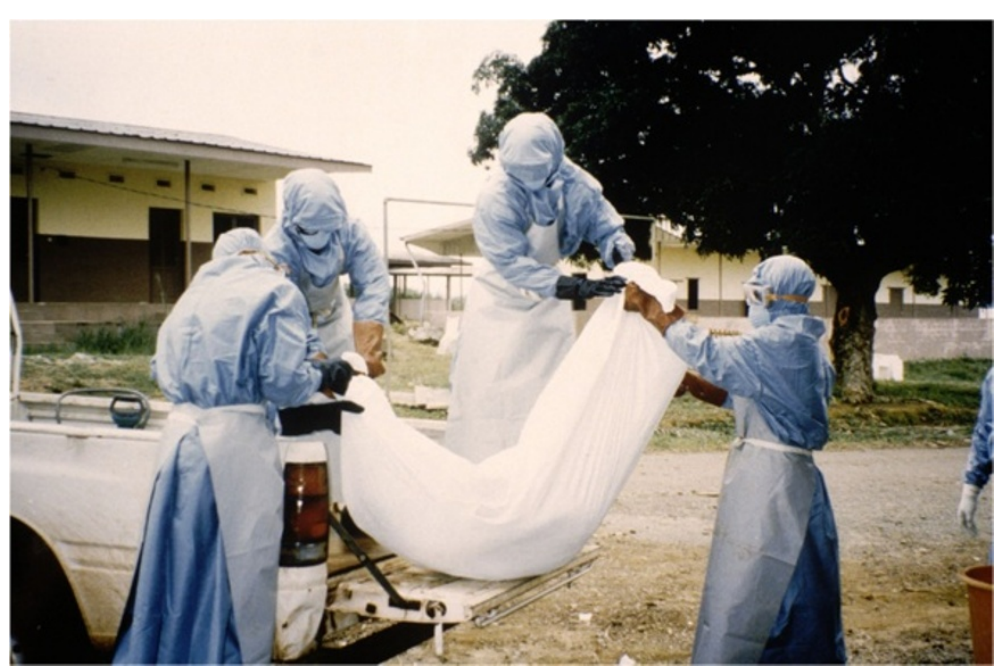

Figure 9 Boarding of a corpse in the vehicle for transportation to the burial site (photo by Jean-Paul Gonzalez, OIRD). 
chain at community and hospital levels, while respecting the traditions as much as possible, and the legitimate wish of relatives to accompany their sick or deceased relatives, in order to restore people confidence.

Received: 26 August 2014 Accepted: 19 September 2014

Published: 3 October 2014

\section{References}

1. Gordon Smith CE, Simpson DI, Bowen ET, Zlotnik I: Fatal human disease from vervet monkeys. Lancet 1967, 2(7526):1119-1121.

2. Negredo A, Palacios G, Vázquez-Morón S, González F, Dopazo H, Molero F, Juste J, Quetglas J, Savji N, De La Cruz Martínez M, Herrera JE, Pizarro M, Hutchison SK, Echevarría JE, Lipkin WI, Tenorio A: Discovery of an ebolavirus-like filovirus in Europe. PLoS Pathog 2011, 7(10):e1002304

3. Kuhn JH, Bào Y, Bavari S, Becker S, Bradfute S, Brauburger K, Rodney Brister J, Bukreyev AA, Caì Y, Chandran K, Davey RA, Dolnik O, Dye JM, Enterlein S, Gonzalez JP, Formenty P, Freiberg AN, Hensley LE, Hoenen T, Honko AN, Ignatyev GM, Jahrling PB, Johnson KM, Klenk HD, Kobinger G, Lackemeyer MG, Leroy EM, Lever MS, Mühlberger E, Netesov SV, et al: Virus nomenclature below the species level: a standardized nomenclature for filovirus strains and variants rescued from cDNA. Arch Virol 2014, 159(5):1229-1237.

4. Ascenzi P, Bocedi A, Heptonstall J, Capobianchi MR, Di Caro A, Mastrangelo E, Bolognesi M, Ippolito G: Ebolavirus and Marburgvirus: insight the Filoviridae family. Mol Aspects Med 2008, 29(3):151-185.

5. Feldmann H, Geisbert TW: Ebola haemorrhagic fever. Lancet 2011, 377(9768):849-862.

6. Groseth A, Marzi A, Hoenen T, Herwig A, Gardner D, Becker S, Ebihara H, Feldmann $\mathrm{H}$ : The Ebola virus glycoprotein contributes to but is not sufficient for virulence in vivo. PLoS Pathog 2012, 8(8):e1002847.

7. Ströher U, West E, Bugany H, Klenk HD, Schnittler HJ, Feldmann H: Infection and activation of monocytes by Marburg and Ebola viruses. J Virol 2001, 75(22):11025-11033.

8. Basler CF, Wang X, Muhlberger E, Volchkov V, Paragas J, Klenk HD, Garcia-Sastre A, Palese P: The Ebola virus VP35 protein functions as a type I IFN antagonist. Proc Natl Acad Sci U S A 2000, 97(22):12289-12294.

9. Kühl A, Pöhlmann S: How Ebola virus counters the interferon system. Zoonoses Public Health 2012, 59(Suppl 2):116-131.

10. Carroll SA, Towner JS, Sealy TK, McMullan LK, Khristova ML, Burt Ff, Swanepoel R, Rollin PE, Nichol ST: Molecular evolution of viruses of the family Filoviridae based on 97 whole-genome sequences. J Virol 2013, 87(5):2608-2616

11. Johnson KM, Lange JV, Webb PA, Murphy FA: Isolation and partial characterisation of a new virus causing acute haemorrhagic fever in Zaire. Lancet 1977, 1(8011):569-571.

12. Bowen ET, Lloyd G, Harris WJ, Platt GS, Baskerville A, Vella EE: Viral haemorrhagic fever in southern Sudan and northern Zaire. Preliminary studies on the aetiological agent. Lancet 1977, 1(8011):571-573.

13. Pattyn $\mathrm{S}$, van der Groen $\mathrm{G}$, Courteille G, Jacob W, Piot P: Isolation of Marburg-like virus from a case of haemorrhagic fever in Zaire. Lancet 1977, 1(8011):573-574.

14. Towner JS, Sealy TK, Khristova ML, Albariño CG, Conlan S, Reeder SA, Quan PL, Lipkin WI, Downing R, Tappero JW, Okware S, Lutwama J, Bakamutumaho B, Kayiwa J, Comer JA, Rollin PE, Ksiazek TG, Nichol ST: Newly discovered Ebola virus associated with hemorrhagic fever outbreak in Uganda. PLoS Pathog 2008, 4(11):e1000212.

15. Le Guenno B, Formenty P, Wyers M, Gounon P, Walker F, Boesch C: Isolation and partial characterisation of a new strain of Ebola virus. Lancet 1995, 345(8960):1271-1274.

16. Jahrling PB, Geisbert TW, Dalgard DW, Johnson ED, Ksiazek TG, Hall WC, Peters CJ: Preliminary report: isolation of Ebola virus from monkeys imported to USA. Lancet 1990, 335(8688):502-505.

17. Barrette RW, Metwally SA, Rowland JM, Xu L, Zaki SR, Nichol ST, Rollin PE, Towner JS, Shieh WJ, Batten B, Sealy TK, Carrillo C, Moran KE, Bracht AJ, Mayr GA, Sirios-Cruz M, Catbagan DP, Lautner EA, Ksiazek TG, White WR, McIntosh MT: Discovery of swine as a host for the Reston ebolavirus. Science 2009, 325(5937):204-206.
18. Leroy EM, Kumulungui $B$, Pourrut $X$, Rouquet $P$, Hassanin A, Yaba P, Délicat A, Paweska JT, Gonzalez JP, Swanepoel R: Fruit bats as reservoirs of Ebola virus. Nature 2005, 438(7068):575-576.

19. Grard G, Biek R, Tamfum JJ, Fair J, Wolfe N, Formenty P, Paweska J, Leroy E: Emergence of divergent Zaire ebola virus strains in Democratic Republic of the Congo in 2007 and 2008. J Infect Dis 2011, 204(Suppl 3):776-784.

20. Barrette RW, Xu L, Rowland JM, Mclntosh MT: Current perspectives on the phylogeny of Filoviridae. Infect Genet Evol 2011, 11(7):1514-1519.

21. Okware SI, Omaswa FG, Zaramba S, Opio A, Lutwama JJ, Kamugisha J, Rwaguma EB, Kagwa P, Lamunu M: An outbreak of Ebola in Uganda. Trop Med Int Health 2002, 7(12):1068-1075.

22. Eichner M, Dowell SF, Firese N: Incubation period of Ebola hemorrhagic virus subtype Zaire. Osong Public Health Res Perspect 2011, 2(1):3-7.

23. World Health Organization: Ebola haemorrhagic fever: fact sheet revised in May 2004. Wkly Epidemiol Rec 2004, 79(49):435-439.

24. Baron RC, McCormick JB, Zubeir OA: Ebola virus disease in southern Sudan: hospital dissemination and intrafamilial spread. Bull World Health Organ 1983, 61(6):997-1003.

25. World Health Organization: Ebola haemorrhagic fever in Sudan, 1976. Report of a WHO/International Study Team. Bull World Health Organ 1978, 56(2):247-270.

26. Report of an International Commission: Ebola haemorrhagic fever in Zaire, 1976. Bull World Health Organ 1978, 56(2):271-293.

27. Bwaka MA, Bonnet MJ, Calain P, Colebunders R, De Roo A, Guimard Y, Katwiki KR, Kibadi K, Kipasa MA, Kuvula KJ, Mapanda BB, Massamba M, Mupapa KD, Muyembe-Tamfum JJ, Ndaberey E, Peters $\mathrm{CJ}$, Rollin PE, Van den Enden E, Van den Enden E: Ebola hemorrhagic fever in Kikwit, Democratic Republic of the Congo: clinical observations in 103 patients. J Infect Dis 1999, 179(Suppl 1):1-7.

28. Khan AS, Tshioko FK, Heymann DL, Le Guenno B, Nabeth P, Kerstiëns B, Fleerackers Y, Kilmarx PH, Rodier GR, Nkuku O, Rollin PE, Sanchez A, Zaki SR, Swanepoel R, Tomori O, Nichol ST, Peters CJ, Muyembe-Tamfum JJ, Ksiazek TG: The reemergence of Ebola hemorrhagic fever, Democratic Republic of the Congo, 1995. Commission de Lutte contre les Epidémies à Kikwit. J Infect Dis 1999, 179(Suppl 1):76-86.

29. MacNeil A, Farnon EC, Wamala J, Okware S, Cannon DL, Reed Z, Towner JS, Tappero JW, Lutwama J, Downing R, Nichol ST, Ksiazek TG, Rollin PE: Proportion of deaths and clinical features in Bundibugyo Ebola virus infection. Uganda Emerg Infect Dis 2010, 16(12):1969-1972.

30. Roddy P, Howard N, Van Kerkhove MD, Lutwama J, Wamala J, Yoti Z, Colebunders R, Palma PP, Sterk E, Jeffs B, Van Herp M, Borchert M: Clinical manifestations and case management of Ebola haemorrhagic fever caused by a newly identified virus strain, Bundibugyo, Uganda, 2007-2008. PLoS One 2012, 7(12):e52986.

31. Borchert M, Mutyaba I, Van Kerkhove MD, Lutwama J, Luwaga H, Bisoborwa G, Turyagaruka J, Pirard P, Ndayimirije N, Roddy P, Van Der Stuyft P: Ebola haemorrhagic fever outbreak in Masindi District, Uganda: outbreak description and lessons learned. BMC Infect Dis 2011, 11:357.

32. Towner JS, Rollin PE, Bausch DG, Sanchez A, Crary S, Vincent M, Lee WF, Spiropoulou CF, Ksiazek TG, Lukwiya M, Kaducu F, Downing R, Nichol ST: Rapid diagnosis of Ebola haemorrhagic fever by reverse transcription PCR in an outbreak setting and assessment of patient viral load as a predictor of outcome. J Virol 2004, 78(8):4330-4341.

33. MacNeil A, Farnon EC, Morgan OW, Gould P, Boehmer TK, Blaney DD, Wiersma P, Tappero JW, Nichol ST, Ksiazek TG, Rollin PE: Filovirus outbreak detection and surveillance: lessons from Bundibugyo. I Infect Dis 2011, 204(Suppl 3):761-767.

34. World Health Organization: Outbreak(s) of Ebola haemorrhagic fever, Congo and Gabon, October 2001-July 2002. Wkly Epidemiol Rec 2003, 78(26):223-228.

35. Dowell SF, Mukunu R, Ksiazek TG, Khan AS, Rollin PE, Peters CJ: Transmission of Ebola hemorrhagic fever: a study of risk factors in family members, Kikwit, Democratic Republic of the Congo, 1995. Commission de Lutte contre les Epidémies à Kikwit. J Infect Dis 1999, 179(Suppl 1):87-91.

36. Centers for Disease Control and Prevention [CDC]: Ebola hemorrhagic fever. CDC 2014, http://www.cdc.gov/vhf/ebola/hcp/case-definition.html.

37. Ksiazek TG, Rollin PE, Williams AJ, Bressler DS, Martin ML, Swanepoel R, Burt FJ, Leman PA, Khan AS, Rowe AK, Mukunu R, Sanchez A, Peters CJ: Clinical virology of Ebola hemorrhagic fever (EHF): virus, virus antigen, and IgG and IgM antibody findings among EHF patients in Kikwit, Democratic Republic of the Congo, 1995. J Infect Dis 1999, 179(Suppl 1):177-187. 
38. Sobarzo A, Ochayon DE, Lutwama JJ, Balinandi S, Guttman O, Marks RS, Kuehne Al, Dye JM, Yavelsky V, Lewis EC: Lobel: Persistent immune responses after Ebola virus infection. N Engl J Med 2013, 369(5):492-493.

39. Fausther-Bovendo $H$, Mulangu S, Sullivan NJ: Ebolavirus vaccines for humans and apes. Curr Opin Virol 2012, 2(3):324-329.

40. Hoenen T, Groseth A, Feldmann H: Current ebola vaccines. Expert Opin Biol Ther 2012, 12(7):859-872.

41. MacNeil A, Rollin PE: Ebola and Marburg hemorrhagic fevers: neglected tropical diseases? PLoS Negl Trop Dis 2012, 6(6):e1546.

42. Emond RT, Evans B, Bowen ET, Lloyd G: A case of Ebola virus infection. Br Med J 1977, 2(6086):541-544.

43. Mupapa K, Massamba M, Kibadi K, Kuvula K, Bwaka A, Kipasa M, Colebunders R, Muyembe-Tamfum JJ: Treatment of Ebola hemorrhagic fever with blood transfusions from convalescent patients. International Scientific and Technical Committee. J Infect Dis 1999, 179(Suppl 1):18-23.

44. Dye JM, Herbert AS, Kuehne AI, Barth JF, Muhammad MA, Zak SE, Ortiz RA, Prugar LI, Pratt WD: Postexposure antibody prophylaxis protects nonhuman primates from filovirus disease. Proc Natl Acad Sci U S A 2012 109(13):5034-5039.

45. Wong G, Qiu X, Olinger GG, Kobinger GP: Post-exposure therapy of filovirus infections. Trends Microbiol 2014, 22(8):456-463.

46. Warren TK, Wells J, Panchal RG, Stuthman KS, Garza NL, Van Tongeren SA, Dong L, Retterer CJ, Eaton BP, Pegoraro G, Honnold S, Bantia S, Kotian P, Chen X, Taubenheim BR, Welch LS, Minning DM, Babu YS, Sheridan WP, Bavari S: Protection against filovirus diseases by a novel broad-spectrum nucleoside analogue BCX4430. Nature 2014, 508:402-405.

47. Clark DV, Jahrling PB, Lawler JV: Clinical management of filovirus-infected patients. Viruses 2012, 4:1668-1686.

48. Jahrling PB, Geisbert TW, Geisbert JB, Swearengen JR, Bray M, Jaax NK, Huggins JW, LeDuc JW, Peters CJ: Evaluation of immune globulin and recombinant interferon-alpha2b for treatment of experimental Ebola virus infections. J Infect Dis 1999, 179(Suppl 1):224-234.

49. Changula K, Kajihara M, Mweene AS, Takada A: Ebola and Marburg virus diseases in Africa: increased risk of outbreaks in previously unaffected areas? Microbiol Immunol 2014, 58(9):483-491.

50. Groseth A, Feldmann H, Strong JE: The ecology of Ebola virus. Trends Microbiol 2007, 15(9):408-416

51. Polonsky JA, Wamala JF, de Clerck H, Van Herp M, Sprecher A, Porten K Shoemaker T: Emerging filoviral disease in Uganda: proposed explanations and research directions. Am J Trop Med Hyg 2014, 90(5):790-793.

52. Ivanoff B, Duquesnoy P, Languillat G, Saluzzo JF, Georges A, Gonzalez JP, McCormick J: Haemorrhagic fever in Gabon. I. incidence of Lassa, Ebola and Marburg viruses in Haut-Ogooué. Trans R Soc Trop Med Hyg 1982, 76(6):719-720

53. Johnson ED, Gonzalez JP, Georges AJ: Filovirus activity among selected ethnic groups inhabiting the tropical forest of equatorial Africa. Trans $R$ Soc Trop Med Hyg 1993, 87(5):536-538.

54. Germain M: Collection of Mammals and Arthropods During the Epidemic of Haemorrhagic Fever in Zaire. In Ebola Virus Haemorrhagic Fever. Edited by Pattyn SR. Amsterdam: Elsevier / North-Holland Biomedical Press; 1978:131-133.

55. Arata AA, Johnson B: Approaches Towards Studies on Potential Reservoirs of Viral Haemorrhagic Fever in Southern Sudan (1977). In Ebola Virus Haemorrhagic Fever. Edited by Pattyn SR. Amsterdam: Elsevier / North-Holland Biomedical Press; 1978:134-139.

56. Leirs H, Mills JN, Krebs JW, Childs JE, Akaibe D, Woollen N, Ludwig G, Peters CJ, Ksiazek TG: Search for the Ebola virus reservoir in Kikwit, Democratic Republic of the Congo: reflections on a vertebrate collection. J Infect Dis 1999, 179(Suppl 1):S155-S163.

57. Morvan JM, Deubel V, Gounon $P$, Nakouné $E$, Barrière $P$, Murri S, Perpète $O$, Selekon B, Coudrier D, Gautier-Hion A, Colyn M, Volehkov V: Identification of Ebola virus sequences present as RNA or DNA in organs of terrestrial small mammals of the Central African Republic. Microbes Infect 1999, 1 (14):1193-1201.

58. Leroy EM, Epelboin A, Mondonge V, Pourrut X, Gonzalez JP, Muyembe-Tamfum $\mathrm{J}$, Formenty P: Human Ebola outbreak resulting from direct exposure to fruit bats in Luebo, Democratic Republic of Congo, 2007. Vector Borne Zoonotic Dis 2009, 9(6):723-728.

59. Pourrut $X$, Kumulungui B, Wittmann T, Moussavou G, Délicat A, Yaba P, Nkoghe D, Gonzalez JP, Leroy EM: The natural history of Ebola virus in Africa. Microbes Infect 2005, 7(7-8):1005-1014.
60. Pourrut X, Délicat A, Rollin PE, Ksiazek TG, Gonzalez JP, Leroy EM: Spatial and temporal patterns of Zaire ebolavirus antibody prevalence in the possible reservoir bat species. J Infect Dis 2007, 196(Suppl 2):176-183.

61. Pourrut X, Souris M, Towner JS, Rollin PE, Nichol ST, Gonzalez JP, Leroy E Large serological survey showing cocirculation of Ebola and Marburg viruses in Gabonese bat populations, and a high seroprevalence of both viruses in Rousettus aegyptiacus. BMC Infect Dis 2009, 9:159.

62. Hayman DTS, Emmerich P, Yu M, Wang L-F, Suu-Ire R, Fooks AR, Cunningham AA, Wood JLN: Long-term survival of an urban fruit bat seropositive for Ebola and Lagos batviruses. PLoS One 2010, 5(8):e11978.

63. Hayman DT, Yu M, Crameri G, Wang LF, Suu-Ire R, Wood JL, Cunningham AA: Ebola virus antibodies in fruit bats, Ghana. West Africa Emerg Infect Dis 2012, 18(7):1207-1209.

64. Reiter P, Turell M, Coleman R, Miller B, Maupin G, Liz J, Kuehne A, Barth J, Geisbert J, Dohm D, Glick J, Pecor J, Robbins R, Jahrling P, Peters C, Ksiazek $\mathrm{T}$ : Field investigations of an outbreak of Ebola hemorrhagic fever, Kikwit, Democratic Republic of the Congo, 1995: arthropod studies. J Infect Dis 1999, 179(Suppl 1):S148-S154.

65. Olson SH, Reed P, Cameron KN, Ssebide BJ, Johnson CK, Morse SS, Karesh WB, Mazet JA, Joly DO: Dead or alive: animal sampling during Ebola hemorrhagic fever outbreaks in humans. Emerg Health Threats J 2012, 5: doi: 10.3402/ehtj.v5i0.9134.

66. Formenty $P$, Boesch C, Wyers M, Steiner C, Donati F, Dind F, Walker F, Le Guenno B: Ebola virus outbreak among wild chimpanzees living in a rain forest of Côte d'Ivoire. J Infect Dis 1999, 179(Suppl 1):S120-S126.

67. Georges AJ, Leroy EM, Renaut AA, Benissan CT, Nabias RJ, Ngoc MT, Obiang PI, Lepage JP, Bertherat EJ, Bénoni DD, Wickings EJ, Amblard JP, Lansoud-Soukate JM, Milleliri JM, Baize S, Georges-Courbot MC: Ebola hemorrhagic fever outbreaks in Gabon, 1994-1997: epidemiologic and health control issues. J Infect Dis 1999, 179(Suppl 1):S65-S75.

68. Karesh W, Reed P: Ebola and great apes in Central Africa: current status and future needs. Bull Soc Pathol Exot 2005, 98(3):237-238.

69. Nkoghe D, Formenty P, Leroy EM, Nnegue S, Edou SY, Ba Jl, Allarangar $Y$, Cabore J, Bachy C, Andraghetti R, de Benoist AC, Galanis E, Rose A, Bausch D, Reynolds M, Rollin P, Choueibou C, Shongo R, Gergonne B, Koné LM, Yada $A$, Roth $C$, Mve MT: Plusieurs épidémies de fièvre hémorragique à virus Ebola au Gabon, octobre 2001 à avril 2002. Bull Soc Pathol Exot 2005, 98(3):224-229.

70. Nkoghe D, Kone ML, Yada A, Leroy E: A limited outbreak of Ebola haemorrhagic fever in Etoumbi, Republic of Congo, 2005. Trans $R$ SoC Trop Med Hyg 2011, 105(8):466-472

71. Formenty P, Libama F, Epelboin A, Allarangar $Y$, Leroy E, Moudzeo $H$, Tarangonia P, Molamou A, Lenzi M, Ait-lkhlef K, Hewlett B, Roth C, Grein T: La riposte à l'épidémie de fièvre hémorragique à virus Ebola en République du Congo, 2003: une nouvelle stratégie? Med Trop 2003, 63:291-295.

72. Thomas DW: The annual migrations of three species of West African fruit bats (Chiroptera: Pteropodidae). Can J Zoology 1983, 61(10):2266-2272.

73. Richter HV, Cumming GS: First application of satellite telemetry to track African straw-coloured fruit bat migration. J Zool 2008, 275(2):172-176.

74. Johnson BK, Wambui C, Ocheng D, Gichogo A, Oogo S, Libondo D, Gitau $L G$, Tukei PM, Johnson ED: Seasonal variation in antibodies against Ebola virus in Kenyan fever patients. Lancet 1986, 1(8490):1160.

75. Pinzon JE, Wilson JM, Tucker CJ, Arthur R, Jahrling PB, Formenty P: Trigger events: enviroclimatic coupling of Ebola hemorrhagic fever outbreaks. Am J Trop Med Hyg 2004, 71(5):664-674.

76. Gautier-Hion A, Michaloud G: Are figs always keystone resources for tropical frugivorous vertebrates? A test in Gabon. Ecology 1989, 70(6):1826-1833.

77. Hewlett BS, Amola RP: Cultural contexts of Ebola in northern Uganda. Emerg Infect Dis 2003, 9(10):1242-1248.

78. Hewlett BS, Epelboin A, Hewlett BL, Formenty P: Medical anthropology and Ebola in Congo: cultural models and humanistic care. Bull Soc Pathol Exot 2005, 98(3):230-236

79. Epelboin A: Rapport de mission anthropologique sur l'épidémie d'Ebola Isiro, $R$. D. Congo, 4 au 30 septembre 2012. France: CNRS-MNHN Paris \& OMS; 2012 [download2.cerimes.fr/canalu/documents/smm/marburg.en.angola.uige. avril.2005.fun.railles.de.crise.le.tailleur.et.les.siens_13719/2012rdc.ebola.rapport. epelboinww.pdf].

80. Bausch DG, Towner JS, Dowell SF, Kaducu F, Lukwiya M, Sanchez A, Nichol ST, Ksiazek TG, Rollin PE: Assessment of the risk of Ebola virus transmission from bodily fluids and fomites. J Infect Dis 2007, 196(Suppl 2):S142-S147. 
81. Kibadi K, Mupapa K, Kuvula K, Massamba M, Ndaberey D, Muyembe-Tamfum JJ, Bwaka MA, De Roo A, Colebunders R: Late ophthalmologic manifestations in survivors of the 1995 Ebola virus epidemic in Kikwit, Democratic Republic of the Congo. J Infect Dis 1999, 179(Suppl 1):S13-S14.

82. Milleliri JM, Tevi-Benissan C, Baize S, Leroy E, Georges-Courbot MC: Épidémies de fièvre hémorragique à virus Ebola au Gabon (1994-2002): aspect épidémiologiques et considérations sur les mesures de contrôle. Bull Soc Pathol Exot 2004, 97:199-205.

83. Heymann DL, Weisfeld JS, Webb PA, Johnson KM, Cairns T, Berquist H: Ebola hemorrhagic fever: Tandala, Zaire, 1977-1978. J Infect Dis 1980, 142(3):372-376.

84. Amblard J, Obiang P, Edzang S, Prehaud C, Bouloy M, Le Guenno B: Identification of the Ebola virus in Gabon in 1994. Lancet 1997, 349(9046):181-182.

85. World Health Organization: Ebola haemorrhagic fever: confirmed case in Côte d'Ivoire and suspect cases in Liberia. Wkly Epidemiol Rec 1995, 70(50):359.

86. World Health Organization: Ebola haemorrhagic fever in Côte d'Ivoire. Wkly Epidemiol Rec 1995, 70(21-52):367.

87. World Health Organization: Ebola haemorrhagic fever, Zaire. Wkly Epidemiol Rec 1995, 70(34):241-242.

88. World Health Organization: Ebola haemorrhagic fever, Gabon. Wkly Epidemiol Rec 1996, 71(9):71.

89. World Health Organization: Outbreak of Ebola haemorrhagic fever in Gabon officially declared over. Wkly Epidemiol Rec 1996 71(17):125-126

90. World Health Organization: Ebola haemorrhagic fever: a summary of the outbreak in Gabon. Wkly Epidemiol Rec 1997, 72(1-2):342.

91. Georges-Courbot MC, Lu CY, Lansoud-Soukate J, Leroy E, Baize S: Isolation and partial molecular characterisation of a strain of Ebola virus during a recent epidemic of viral haemorrhagic fever in Gabon. Lancet 1997, 349(9046):181.

92. Boumandouki P, Formenty $P$, Epelboin A, Campbell P, Atsangandoko C, Allarangar $\mathrm{Y}$, Leroy EM, Kone ML, Molamou A, Dinga-Longa O, Salemo A, Kounkou RY, Mombouli V, Ibara JR, Gaturuku P, Nkunku S: Prise en charge des malades et des défunts lors de l'épidémie de fièvre hémorragique à virus Ebola à Mbandza et Mbomo d'octobre à décembre 2003 au Congo. Bull Soc Pathol Exot 2005, 98(3):218-223.

93. World Health Organization: Outbreak of Ebola haemorrhagic fever in Yambio, south Sudan, April - June 2004. Wkly Epidemiol Rec 2005, 80(43):370-375.

94. World Health Organization: Ebola haemorrhagic fever, Uganda - end of the outbreak. Wkly Epidemiol Rec 2008, 83(10):89-90.

95. World Health Organization: Ebola, Uganda. Wkly Epidemiol Rec 2011 86(22):221.

96. World Health Organization: Uganda: Ebola (situation as of 27 August 2012) 2012. http://www.afro.who.int/en/clusters-a-programmes/dpc/ epidemic-a-pandemic-alert-and-response/outbreak-news/3674-ugandaebola-situation-as-of-27-august-2012-.html.

97. Parkes-Ratanshi R, Elbireer A, Mbambu B, Mayanja F, Coutinho A, Merry C: Ebola outbreak response; experience and development of screening tools for viral haemorrhagic fever (VHF) in a HIV center of excellence near to VHF epicentres. PLoS One 2014, 9(7):e100333.

98. World Health Organization: Ebola haemorrhagic fever, Uganda - update. Wkly Epidemiol Rec 2012, 87(49-50):493.

99. World Health Organization Regional Office for Africa: DR Congo: Ebola. Bull World Health Organ 2012, 2:8.

100. Mukwamba FKN: Déclaration de la fin de l'épidémie de fièvre hémorragique à virus Ebola survenue dans le District Sanitaire du Haut-Uélé Ouest, Province Orientale, RD Congo:: Government of the Democratic Republic of the Congo; 2012. http://reliefweb.int/report/democratic-republic-congo/d\%C3\% A9claration-de-la-fin-de-1\%E2\%80\%99\%C3\%A9pid\%C3\%A9mie-de-fi\%C3\% A8vre-h\%C3\%A9morragique-\%C3\%A0-virus.

101. World Health Organization: Suspected viral haemorrhagic fever outbreaks in Sudan and Zaire. Wkly Epidemiol Rec 1976, 51(41):321.

102. World Health Organization: Viral haemorrhagic fever. Zaire. Wkly Epidemio/ $\operatorname{Rec} 1977,52(1): 2$.

103. World Health Organization: Viral haemorrhagic fever. Sudan. Wkly Epidemiol Rec 1979, 54(41):319.

104. World Health Organization: Yellow fever. Gabon. Wkly Epidemiol Rec 1995, 70(9):64.
105. Centers for Disease Control and Prevention: Outbreak of Ebola hemorrhagic fever - Uganda, August 2000- January 2001. Morb Mortal Wkly Rep 2001, 50(5):73-77.

106. Heymann DL, Barakamfitiye D, Szczeniowski M, Muyembe-Tamfum JJ, Bele O, Rodier G: Ebola hemorrhagic fever: lessons from Kikwit, Democratic Republic of the Congo. J Infect Dis 1999, 179(Suppl 1):S283-S286.

doi:10.1186/1678-9199-20-44

Cite this article as: Chippaux: Outbreaks of Ebola virus disease in Africa: the beginnings of a tragic saga. Journal of Venomous Animals and Toxins including Tropical Diseases 2014 20:44.

\section{Submit your next manuscript to BioMed Central and take full advantage of:}

- Convenient online submission

- Thorough peer review

- No space constraints or color figure charges

- Immediate publication on acceptance

- Inclusion in PubMed, CAS, Scopus and Google Scholar

- Research which is freely available for redistribution

Submit your manuscript at www.biomedcentral.com/submit
C BioMed Central 